\title{
Utilizing Sulawesi Folktales into the Teaching of Reading Comprehension
}

\author{
Rahmawati Upa' *', Heryanto Mangalik ${ }^{2}$ \\ 1, 2 Universitas Cokroaminoto Palopo \\ *rahmawatiupa@uncp.ac.id
}

\begin{abstract}
Utilizing local wisdom into the teaching process has been a national agenda in Indonesia Curriculum today but it commonly pay less attention by the teacher including EFL teachers. Meanwhile Indonesia is well known for its diversity of local wisdom. Local wisdom in this case included folktales. This research was done in order to find out whether or not the utilization of Sulawesi folktales into the teaching of reading comprehension is effective. This research applied quantitative method obtained through pre-test - treatment - post-test. The subjects of this research were the fourth semester students of English Language Education Study Program of Universitas Cokroaminoto Palopo. After having data analysis, then the researcher come to the conclusion that the utilization of Sulawesi folktales into the teaching of reading comprehension is effective to improve the students' reading comprehension. It is proofed through the mean score of the pretest (5.05) and the mean score of the posttest (7.30). The standard deviation of pretest is I.27 and the posttest is 0.97 , while t-test is $0.00 \mathrm{I},(\alpha)=0.05$.
\end{abstract}

Keywords: Sulawesi folktales; reading comprehension; students' achievement

\section{Introduction}

English reading comprehension is a complex thing to be done by the students in EFL studies since they have to understand what they have read. There are some ways done by them in order to understand it, including looking up the meaning of the words in the dictionary but after doing it, they are still fail to understand the text. Some factors can cause of it, one of them is the students' background knowledge about the text they have read. As suggested by Duke and Pearson (2002:206) that in order to understand the text being read, students have to compare and integrate it to their prior knowledge, but the problem arise then is when the students do not have any background knowledge on what they are reading and this problem happened to the most of students in Indonesia now including in Sulawesi.

Referring to this problem then the researcher is interested in Utilization Sulawesi local culture into the teaching of reading comprehension since the use of local culture brings some benefits for both teachers and students. For teachers, it plays very important role in improving motivation, engagement and interaction among the students (Segni and Davidson: 2016) meanwhile for students, it motivates them to understand more the language since the content is familiar for them (MC Kay: 2000). In the teaching of reading comprehension in this research, the local culture content which integrated was Sulawesi folktale.

Linguistic knowledge can affect one's reading, but cultural factors plays a more important role in the reading process, most of the true and serious reading barriers are not only from the language knowledge itself, but also caused by cultural differences between the target language and our mother tongue. Sometimes we find that the students may recognize and 
understand the meaning of each in the text, but they are still not so clear about the meaning of the whole sentences or paragraphs (Choudhury, 20I4:7).

Many people believe that teaching English should be about English element and English culture, they less consider that the students' local culture must exist in teaching English as stated by Richards and Renandya (2010) that effective teaching material is the one that providing cultural and linguistic input and rich selection of integrated activities. A related assertion stated by Kramsch in Prastiwi (2013) that cultural exists whenever the language is being taught. Functioning EFL as the context for local cultural knowledge acquisition makes the students experience a negotiation between their own culture and the cultural knowledge of the target language. Being introduced to the target culture through teaching materials and class activities essentially helps the students to recognize their own identity that identity formation happened. From this assertion, it can be assume that learning foreign language can be done comprehensively if the context of the target language culture is understood by the students. In order to understand the culture of the target language, students should have knowledge on their own local culture to help them catching the cultural concept of the target language by comparing their similarities and differences.

Various studies have been done in Utilization of folktale into reading comprehension teaching (Wijayanti, 2017; Amrinah \& Kamilah Nur, 2016) but seldom of them specialized it on Sulawesi folktale, while as a tribe, Sulawesi has rich folktale, unfortunately most of them have not been explored, exhibited, and exerted valuably. So in this research, the researcher utilized folktale from Sulawesi into the teaching of English reading comprehension. The folktales used were Sulawesi folktale which have been translated into English.

In this research, the researchers utilize Sulawesi folktales into the teaching of reading comprehension since the researchers are sure that it will build students motivation and participation in the classroom then it will affect their achievement. There are many books which include folktales as the learning material but the folktales are not from their own environment and they are very general and it makes them unmotivated since they have been reading that folktales since they were children. There are also some books which include folktales which are very unfamiliar for the students and it cause the students unmotivated since they don't have any background knowledge about it. That's why the researchers tried to utilize the folktale which have been familiar for them and come from their own environment, but they are seldom utilized into the teaching especially English teaching.

According to Misch (2008:3) folktale is a general term for the various kind of narrative prose literature in the oral tradition of the world. Folktales always present something which sometimes does not make sense but it is true. It does not mean folktale asks the audience to believe in things that do not make sense and do things beyond his limits but through this story of man trying to portray the other side of life as legend, myths, fables, parables, allegories, folktale, ghost stories and many others. There are some reasons of using folktale in the teaching of foreign language as suggested by Fabusuyi (2014:246) that Utilization folktales into the teaching of foreign language can be done since it can enhance quick learning, support classroom participation, and enlarge students' vocabulary. Other impacts of utilizing folktale in reading comprehension teaching also found by Yusuf Onyi (2017), he found that the use of folktale can stimulate students' interest in the reading class, students' involvement in discussion, enhanced students' self-confidence and even it makes the poor students active. 


\section{Method}

This research was carried out with fourth semester students of English Education Study Program of Universitas Cokroaminoto Palopo with one group pretest -posttest design. There were four classes which consisted of 35 students in each class as the population of this research. The subjects were randomly assigned then it was chosen 20 students as the sample. The sample then taught for six meeting using Sulawesi folktales as the teaching material. Each meeting, the researcher gave one Sulawesi folktale to the students with 20 multiple choice test and five essay test. During the treatment, the researcher used various teaching methods and some Sulawesi folktales. The folktales were Princess Tandampalik, Bagga Stone, the legend of Pamboang, Lagaligo, Latongko Tongko, and La Upe'. After doing the treatment, then the researchers gave posttest. The t-test was used to measure the gain score in the pretest and posttest.

\section{Result \& Discussion}

This research aims at finding out the effect of utilization of Sulawesi folktale on the students' reading comprehension. The researchers hypothesized that the utilization of Sulawesi folktale into the teaching of reading comprehension can bring good effect on students' reading comprehension achievement. The data were collected through pre-test treatment - posttest design and analyzed through SPSS. The bar chart below shows the result of students' score classification in pretest and posttest.

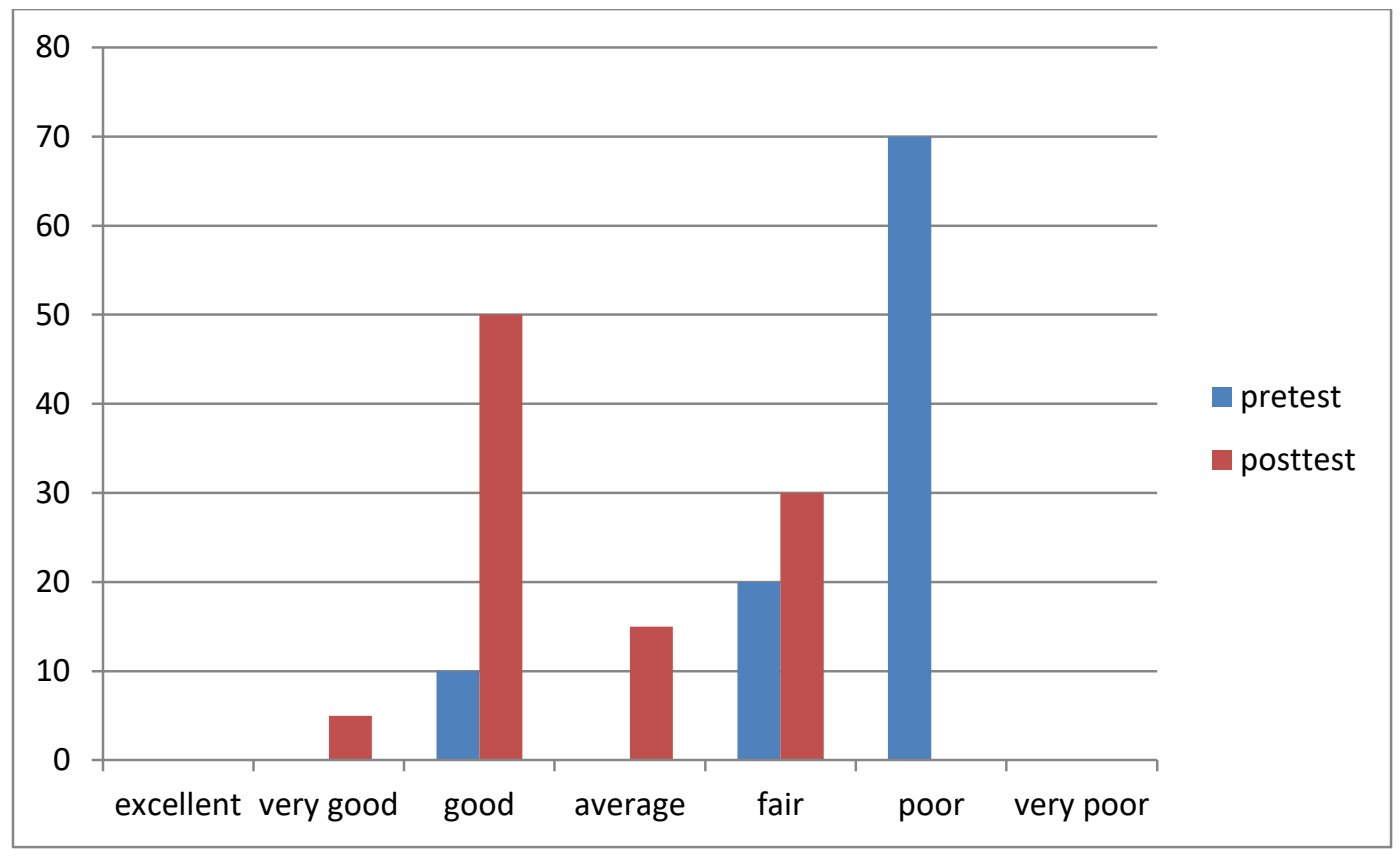

Figure I. The students' score classification in pretest and posttest

The bar chart illustrates that the rate percentage of the posttest was higher than the percentage in the pretest. In the pre-test, most of students get poor score, it reaches $70 \%$. It is followed by fair classification where there are $20 \%$ student get it but there are only $10 \%$ students get good classification. Meanwhile in the post-test, the highest classification got by the students is good classification. It reaches $50 \%$ then it followed by fair and average classification (30\% and 15\%). Very good classification is only obtained by $5 \%$ students.

One sample $t$ test was carried out to determine whether there is a statistically significant difference between pre-test and post-test. Table I represents the result. 
Table I. Result of the t-test of the mean score in pre-test and post-test

\begin{tabular}{llllll}
\hline & Mean & $\mathrm{N}$ & Std. Deviation & Std. Error Mean \\
\hline \multirow{2}{*}{ Pair I } & Pretest & 5.0500 & 20 & 1.27630 & .28539 \\
& Posttest & 7.3000 & 20 & .97872 & .21885 \\
\hline
\end{tabular}

Table I shows that there is different mean score of the pretest and posttest where the mean score of the posttest is higher than the mean score of the pretest $(5.05<7.30)$. It can be seen that the significance ( $t-$ Test) is $0.00 \mathrm{I}$ and $(\alpha)$ is 0 . 05 . It means that $t$ - test is smaller than $(\alpha)$, so there is a significant different between pretest and posttest of students' reading comprehension before and after the researcher give the treatment. It is concluded that null hypothesis $(\mathrm{Ho})$ is rejected, while alternative hypothesis $\left(\mathrm{H}_{1}\right)$ is accepted because the result of the posttest that was done after treatment is greater than the result of the pretest that was done before treatment.

In this research, the researchers utilized Sulawesi folktales into the teaching of reading by giving some printed English folktales from Sulawesi and asked the students to read and try to comprehend it. To check the students' understanding, the researchers' gave some question to the students and asked them to answer it. The students were also asked to express the moral value that they can get form the folktales. The teaching and learning process using Sulawesi folktales is easier for the same background of the students. It made the students responded it well because they were easy to understand the moral values inserted in that local folktales.

The researchers demonstrate that the positive effect of the students' reading comprehension achievement was attributed to the utilization of Sulawesi folktale as the teaching material. This positive effect may be attributed to many reasons. Firstly, the Sulawesi folktale which was utilized into the teaching of reading comprehension is the folktales which come from the students' area. It may have encouraged the students to have high motivation and spirit in understanding the reading comprehension since they wondered to know the story around themselves. Second, some of the folktales utilized into the teaching of reading comprehension have been familiar for the students and automatically they have background knowledge about it so this supports them to participate more in the classroom. It support the theory which proposed by Fabusuyi (2014:246) who said that the used of folktale in teaching can support classroom participation.

The utilization of Sulawesi Folktale into the teaching of reading comprehension is effective to improve students' reading achievement. It builds students' motivation, spirit and interest in the reading comprehension learning process, stimulated discussion, and enhanced students' self-confidence to participate more in the teaching process. It even made poor students literate and showed their ability.

Although the hypothesis proposed in this research is achieved, there were still many areas of further inquiry within the framework of the study. There are questions still unanswered about this research theme which could be answered in further researches. One area the researchers found lack was the availability of the Sulawesi folktale which can be used by the teacher in their teaching. As information that in this research, the folktales used by researchers were the folktales which were searched by the researcher from the internet and other references and translated into English. Further research is needed to think of how to make folktale available so it is easy for the teacher to use it in their teaching. In addition, it 
would be very interesting to integrate Sulawesi folktale into the teaching of other English skill, like speaking, listening, and writing.

\section{Conclusion}

After analyzing the data of this research, then the researchers can conclude that the utilization of Sulawesi folktale is effective to teach reading comprehension. It is proven by the mean score of the pretest is 5.05 and the mean score of the post-test is 7.30 . The standard deviation of pretest is 1.27 and the standard deviation of the posttest is 0.97 , while t-test is $0.00 \mathrm{I}$ and $(\alpha)$ is 0.05 .

\section{References}

Amrinah R. \& Kamilah, N. (2016) Using Folktales to Encourage Extensive Reading in L2. Journal of Language Education in ASIA, 7(I).

Choudhury, U.R. (20I4). The Role of Culture in Teaching of English as a Foreign Language. International Journal of Multidisciplinary Research.

Duke \& Pearson, D. (2002). Effective Practices for Developing Reading Comprehension. International Reading Asociation.

Fabusuyi, A. (20I4). Intergrating Folktales in the teaching of German- A Practical Approach. International Journals of Humanities and Social Science, 4(I I).

McKay, S. (2000). Teaching English as an International Language: Implications for Cultural Materials in the Classroom. TESOL Journal, 9(4).

Misch. M. (2008). Teaching Folktales. Nordestedt: Books on Demand GmBH

Prastiwi, Y. (2013) Transmitting Local Cultural Knowledge through English as a Foreign Language (EFL) Learning as a means of fostering "Unity and Diversity" Academic Journal of Interdisciplinary Study. Italy. MCSER Publishing

Richards, J.C. \& Renandya, W.A. (Eds). (2010) Methodology in Language Teaching, an Anthology of Current Practice. Cambridge: Cambridge University Press.

Segni, B. \& Manjula, D. (2016). The Practicing of Teaching English as a Foreign Language Using Local Cultural Content. Research Journal of English Language and Literature (RJELAL), 4(4).

Wijayanti, M.D.F. (20I7). Improving students' Reading Ability by Using Local Folklore Comics.

Yusuf, O.H. (2017). Impact of the Teacher's Use of Folktale on the Performance of Pupils in Reading Comprehension in Primary School in Kaduna State, Nigeria. The Online Journal of Quality in Higher Education, 4(4). 